Pediyatrik Kalp Cerrahisinde Transfüzyon: Prospektif, Gözlemsel Çalışma

Feride Karacaer $\bullet$ Ebru Biricik ๑

Murat Türkeün Ilgınel ๑

Demet Lafli Tunay $\odot$

\section{Transfusion in Pediatric Heart Surgery: A Prospective, Observational Study}

Etik Kurul Onayı: Çukurova Üniversitesi Tıp Fakültesi Klinik Araştırmalar Etik Kurulu’ndan onay alınmıştır (75 / 02.03.2018).

Çıkar Çatışması: Hiçbir kurum ve kişi ile çıkar çatışmamız yoktur.

Finansal destek: Finansal destek kullanıımamıștır.

Hasta onamı: Çalışmaya dâhil edilen katıımcılardan bilgilendirilmiş onam alınmıştır.
Ethics Committee Approval: Approval was obtained from the Clinical Research Ethics Committee of Çukurova University Faculty of Medicine ( 75 / 02.03.2018)

Conflict of Interest: We have no conflict of interest with any institution or person. Funding: The study was carried out without funding.

Informed Consent: Informed consent was obtained from participants included in the study.

Cite as: Karacaer F, Biricik E, Türkeün Ilgınel M, Lafli Tunay D, Topçuoğlu MŞ. Pediyatrik kalp cerrahisinde transfüzyon: Prospektif, gözlemsel çalışma, GKDA Derg 2019;25(2):102-12.

öz

Amaç: Kalp cerrahisi geçiren pediyatrik hastalarda kan ve kan ürünleri transfüzyonu kaçııılmaz olabilmektedir. Çalışmamızda, bu hastalarda, kan ve kan ürünlerinin transfüzyonu ile ilişkili faktörlerin ve risklerin belirlenmesi amaçlanmıştır.

Yöntem: Preoperatif demografik veriler, kardiyopulmoner baypas (KPB) ve operasyon süresi, KPB girisindeki, $K P B$ sırasındaki ve ayrılmadan sonraki, ameliyat sonundaki hematokrit ve hemoglobin değerleri kaydedildi. KPB sırasında ulaşılan en düşük vücut ISısı, intraoperatif dönemde kullanılan kristalloid, kolloid, eritrosit süspansiyonu (ES), taze donmuş plazma (TDP), trombosit süspansiyonu (TS), kriyopresipitat miktarı kaydedildi. Postoperatif dönemde; yoğun bakım ünitesinde (YBÜ) verilen kan ve kan ürünleri miktarı, YBÜ’nde ve hastanede kalıs süreleri, mortalite kaydedildi.

Bulgular: Calıșmaya 83 çocuk dahil edildi. ES transfüzyonu RACHS1: 3 olan hastalarda, RACHS1: 2 olan hastalardan yüksekti $(p=0,009)$. Yas ile postoperatif ES, intraoperatif ve postoperatif dönemdeki toplam ES ve toplam TDP transfüzyonu arasında negatif korelasyon saptandı. KPB süresi ile intraoperatif ES ve TDP, postoperatif ES, $T D P$, kriyopresipitat tüketimi, toplam ES ve toplam TDP tüketimi arasında pozitif korelasyon belirlendi. Siyanotik çocukların intraoperatif ES ve TDP tüketimi asiyanotik çocuklardan yüksekti (ES $p=0.002$; TDP $p=0.002$ ). Postoperatif dönemde siyanotik çocukların kriyopresipitat tüketimi yüksekti $(p=0.026)$. 15 hastanın eksitus olduğu belirlendi. Eksitus olan hastalarda postoperatif dönemdeki ES ve TDP (ES $p=0.004, T D P p=0.003$ ), toplam ES ve TDP miktarının yüksek olduğu saptandı (toplam ES $p=0.001$, toplam TDP $p=0.003$ ).

Sonuç: Açık kalp cerrahisi geçiren çocuklarda intraoperatif ve postoperatif transfüzyon oranlarının hastanın yașı, RACHS1 skoru, KPB süresi, vücut ISIsı ve siyanoz ile ilișkili olduğu belirlenmiștir. Eksitus olan hastalarda ES ve TDP transfüzyon miktarlarının yüksek olduğu saptanmıştır.

Anahtar kelimeler: pediyatrik kalp cerrahisi, kardiyopulmoner baypas, transfüzyon

\section{ABSTRACT}

Objective: Transfusion of blood and blood products may be unavoidable in pediatric patients undergoing cardiac surgery. The aim of this study was to determine the factors and risks associated with transfusion of blood and blood products in these patients.

Method: Preoperative demographic data, cardiopulmonary bypass (CPB) and operation times were recorded. Hematocrit and hemoglobin values were recorded at the beginning, during and at the end of CPB. The lowest body temperature during CPB, intraoperative consumptions of crystalloid, colloid, blood, blood products were recorded. The consumption of blood and blood products, length of stay intensive care unit (ICU) and hospital, and mortality were recorded during the postoperative period.

Results: Eighty-three children were included in the study. Intraoperative transfusion of erythrocyte suspension (ES) was more frequently applied in patients with RACHS1: 3 when compared with the patients with RACHS1: $2(p=0.009)$. A negative correlation was detected between age and postoperative $E S$, total erythrocyte and total fresh frozen plasma (FFP) transfusions during intraoperative, and postoperative periods. A a positive correlation was determined between $C P B$ duration and intraoperative erythrocyte and FFP, postoperative erythrocyte, FFP, cryoprecipitate, total erythrocyte and total FFP consumptions. The intraoperative ES and FFP consumptions, the postoperative cryoprecipitate consumptions were higher in cyanotic children (ES $p=0.002$; FFP $p=0.002$, cryoprecipitate $p=0.026$ ) when compared with acyanotic children. Fifteen patients died. Postoperative ES and $F F P$, total erythrocyte and FFP consumptions were higher in the deceased patients (total ES $p=0.001$, total FFP $p=0.003$ ).

Conclusion: A correlation was detected between intraoperative, and postoperative transfusion rates, age, RACHS1 scores, body temperatures of the patients, duration of CPB, and presence of cyanosis in children undergoing open heart surgery. Higher rates of ES and FFP transfusions were detected in exited patients.
Alındığı tarih: 04.03.2019

Kabul tarihi: 21.05.2019

Yayın tarihi: 30.06 .2019

Feride Karacaer

Cukurova Üniversitesi Tıp Fakültesi Balcalı Hastanesi Anesteziyoloji ve Reanimasyon Anabilim Dalı

01330 Sarıçam

Adana-Türkiye

- feridekaracaer@gmail.com ORCiD: 0000-0002-1048-6505

E. Biricik 0000-0002-3355-198X

M. T. Ilgınel 0000-0001-9183-9124 D. L. Tunay 0000-0002-7984-1800 Çukurova Üniversitesi Tıp Fakültesi Balcalı Hastanesi Anesteziyoloji ve Reanimasyon Anabilim Dalı Adana-Türkiye

M. Ş. Topçuoğlu 0000-0001-6848-2577 Çukurova Üniversitesi Tıp Fakültesi Balcalı Hastanesi Kardiyovasküler Cerrahi Anabilim Dalı Adana-Türkiye

Keywords: pediatric heart surgery, cardiopulmonary bypass, transfusion

(C) Telif hakkı Göğüs Kalp Damar Anestezi ve Yoğun Bakım Derneği'ne aittir. Logos Tıp Yayıncılık tarafindan yayınlanmaktadır Bu dergide yayınlanan bütün makaleler Creative Commons Atff-Gayri Ticari 4.0 Uluslararası Lisansı ile lisanslanmıştır.

(c) Copyright The Society of Thoracic Cardio-Vascular Anaesthesia and Intensive Care. This journal published by Logos Medical Publishing. Licenced by Creative Commons Attribution-NonCommercial 4.0 International (CC BY-NC 4.0) 


\section{Giriş}

Her yıl daha çok sayıda çocuk kardiyopulmoner baypas (KPB) ile kalp ameliyatı geçirmektedir. Açık kalp cerrahisi geçiren pediyatrik hastalarda hemodilüsyon, hemoliz ve yetersiz hemostaz nedeniyle kan ve kan ürünleri transfüzyonu kaçınılmaz olabilmektedir ${ }^{[1,2]}$. Cerrahi ameliyat geçiren hastaların oldukça küçük bir kısmını oluşturan bu hasta grubu, kan ürünlerinin tüketiminde önemli bir paya sahiptir ${ }^{[3,4]}$. Keung ve ark. ${ }^{[5]}$ KPB ile kardiyak ameliyat geçiren çocuklarda eritrosit transfüzyon oranını $\% 79$ olarak bildirmişlerdir. İntraoperatif transfüzyon, bu hastalarda oksijen taşıma kapasitesini arttırarak yarar sağlamakta ise de beraberinde birçok riski taşıyabilmektedir. Son yıllarda yapılan çalışmalarda, kan ve kan ürünleri transfüzyonunun artan infeksiyon sıklı̆̆ı, uzamış mekanik ventilasyon tedavisi, yoğun bakım ünitesi (YBÜ) ve hastanede kalış süresinde uzama ve mortalite ile ilişkili olduğu bildirilmiştir ${ }^{[6-8]}$.

Konjenital kalp cerrahisi geçiren çocuklarda KPB sırasında optimal hematokrit (Htk) düzeyi halen tartışılmaktadır. Erişkinlerde transfüzyonun genel komplikasyon oranı 1.000 ünite başına 2,5 komplikasyon iken, çocuklarda 1.000 ünite transfüzyon başına 10.7 komplikasyondur. Sonuç olarak, kan nakli ile ilgili risklerin ve masrafların çok büyük olduğu kabul edilmektedir ${ }^{[9]}$.

Kan transfüzyonunun yarar ve risklerini dengelemek, özellikle çocuklarda, oldukça karmaşık bir konudur. Çünkü konjenital kalp hastalığı (KKH) olan çocuklarda transfüzyon tedavisi hastanın yaşı, siyanotik veya asiyanotik olması, mevcut kardiyak anomalisi, gelişme geriliği gibi pek çok faktörden etkilenmektedir ${ }^{[10]}$.

Çalışmamızda, kliniğimizde KPB ile açık kalp cerrahisi geçiren pediyatrik hastalarda, kan ve kan ürünlerinin transfüzyonu ile ilişkili faktörlerin ve risklerin belirlenmesi amaçlanmıştır.

\section{GEREÇ ve YÖNTEM}

Prospektif ve gözlemsel şekilde yapılması planlanan çalışmamıza Çukurova Üniversitesi Tıp Fakültesi Klinik Araştırmalar Etik Kurulu'ndan Etik Kurul onayı alındıktan sonra (75/02.03.2018), Mart 2018-Aralık 2018 tarihleri arasında, konjenital kalp hastalığı nedeniyle açık kalp cerrahisi geçirecek 16 yaş ve altındaki hastalar dâhil edildi. Preoperatif renal yetmezliği veya hepatik hastalığı olan hastalar çalışma dışında bırakıldı.

Hastaların preoperatif değerlendirmesinde; hastanın yaşı, ağırlığı, varsa eşlik eden hastalığı, geçirilmiş operasyon bilgisi kaydedildi. Preoperatif dönemde periferik oksijen saturasyonu $\left(\mathrm{SaO}_{2}\right) \leq \% 85$ olan hastalar siyanotik hasta olarak kabul edildi. Preoperatif $\mathrm{Htk}$ ve hemoglobin $(\mathrm{Hb})$ değeri, KKH tanısı kaydedildi. Ayrıca preoperatif RACHS1 skoru (risk adjustment for surgery for congenital heart disease, konjenital kalp hastalığında cerrahi için risk düzenlemesi) kaydedildi ${ }^{[11]}$.

Hastaların intraoperatif değerlendirmesinde; KPB süresi, aortik kros klemp süresi, KPB girişindeki Htk ve $\mathrm{Hb}$ değeri, KPB sırasındaki ve ayrılmadan sonraki $\mathrm{Htk}$ ve $\mathrm{Hb}$ değeri ve heparinin protamin ile ters çevrilmesinden sonraki $\mathrm{Htk}$ ve $\mathrm{Hb}$ değeri kaydedildi. KPB sırasında ulaşılan en düşük vücut ISISI, idrar miktarı kaydedildi. İntraoperatif dönemde KPB öncesinde, sırasında ve sonrasında santral venöz oksijen saturasyonu $\left(\mathrm{SvO}_{2}\right)$, laktat düzeyi kaydedildi. İntraoperatif dönemde kullanılan kristalloid ve yapay kolloid miktarı, eritrosit süspansiyonu (ES), taze donmuş plazma (TDP), trombosit süspansiyonu (TS) ve kriyopresipitat miktarı kaydedildi. İntraoperatif dönemde kullanılan vazoaktif ajanlar (dopamin, dobutamin, adrenalin) kaydedildi. İnotropik desteğin kümülatif indeksi, Wernovsky ve ark. ${ }^{[12]}$ tarafından önerilen formül ile, inotropik skor (IS) olarak hesaplanarak kaydedildi. IS: dopamin dozu $\left(\mu \mathrm{g} \mathrm{kg}{ }^{-1} \mathrm{dk}^{2}\right)+$ dobutamin dozu $\left(\mu \mathrm{g} \mathrm{kg}{ }^{-1} \mathrm{dk}^{2}{ }^{2}\right)+100 \mathrm{x}$ adrenalin dozu $\left(\mu \mathrm{kg}^{-1} \mathrm{dk}^{2}\right)+$ $100 \times$ noradrenalin dozu $\left(\mu \mathrm{gg}^{-1} \mathrm{dk}^{2}{ }^{2}\right)$.

Hastaların postoperatif dönem değerlendirmesinde; 
YBÜ'nde verilen kan ve kan ürünleri miktarı, YBÜ’nde kalış süreleri, hastanede kalış süreleri ve mortalite kaydedildi.

\section{Kliniğimizde Uyguladığımız Protokol}

Preoperatif 6 saatlik açıı sonrası, 6 aydan küçük bebekler premedikasyon uygulanmadan, daha büyük çocuklar ise intravenöz (iv) yolla $2 \mathrm{mg} / \mathrm{kg}$ ketamin (Ketalar, Pfizer) veya $0.05 \mathrm{mg} / \mathrm{kg}$ midazolam (Dormicum amp, Deva) verilerek sedatize edilip operasyon odasına alınmaktadır. Ameliyat odasında rutin monitörizasyon (elektrokardiyografi (EKG), $\mathrm{SaO}_{2}$, non-invaziv kan basıncı ölçümü) yapılmaktadır. Anestezi indüksiyonundan sonra invaziv arteriyel kan basıncı takibi ve kan gazı örneklemesinde kullanımak üzere arteriyel kanülasyon uygulanmaktadır. Entübasyon sonrasında tüm hastalara, santral venöz basınç takibi (SVB) ve vazoaktif ilaçların infüzyonu amacıyla santral venöz kateter ve idrar miktarının takibi için idrar sondası takılmaktadır.

Kliniğimizde anestezi indüksiyonunda propofol (2 $\mathrm{mg} / \mathrm{kg}$, Propofol \%1, Fresenius) veya pentotal (4-5 $\mathrm{mg} / \mathrm{kg}$, Pental, I.E. Ulagay) ile iv indüksiyon veya sevofluran (Sevorane, Abbot) ile inhalasyon indüksiyonu kullanılmaktadır. Ayrıca indüksiyonda tüm hastalara $5 \mu \mathrm{g} / \mathrm{kg}$ fentanil (Talinat amp, Vem ilaç) uygulanmakta ve kas gevşetici olarak $0.6 \mathrm{mg} / \mathrm{kg}$ roküronyum (Esmeron, MSD) kullanılmaktadır. Anestezi idamesine ise sevofluran inhalasyonu (\%2-3) ve fentanil infüzyonu $(5 \mu \mathrm{g} / \mathrm{kg} / \mathrm{sa})$ ile devam edilmektedir.

Kan gazı örneklemesi ve ACT için kan örneği alınarak KPB sırasında ACT'nin 480 üzerinde olması için 3-5 $\mathrm{mg} / \mathrm{kg}$ heparin santral venöz kateter aracılığıyla verilmektedir. KPB'tan ayrıldıktan sonra heparinin nötralizasyonu için 1:1 oranında protamin kullanılmaktadır. Tüm hastalara anestezi indüksiyonu sonrası 6 $\mathrm{mg} / \mathrm{kg}$ traneksamik asit bolus şeklinde uygulanmakta, ameliyat sonunda protamin ile heparinin etkisi geri döndürüldükten sonra $6 \mathrm{mg} / \mathrm{kg}$ daha aynı şekilde verilmektedir.

Kardiyopulmoner baypas yönetiminde, başlangıç solüsyonu olarak ES ve tamamlayıcı elektrolit solüsyonu kullanılmaktadır. Kros klemp koyulduktan sonra antegrad hipotermik kan kardiyoplejisi ile kardiyak arrest sağlanmaktadır. Sentrifugal pompa akımı (nonpulsatil) $10 \mathrm{~kg}$ kadar olan hastalar için $150-200 \mathrm{~mL} /$ $\mathrm{kg} / \mathrm{dk}, 10 \mathrm{~kg}$ üzeri olanlarda $2.4-2.6 \mathrm{l} / \mathrm{dk} . / \mathrm{m}^{2}$ olarak ayarlandı. Kan gazı analizinde $\alpha$-stat yöntemi kullanılmaktadır.

Intraoperatif kan transfüzyonu; KPB sırasında hedef hematokrit düzeyi \%28-30 olarak belirlenmektedir. KPB'tan çıktıktan sonra rutin olarak koagülasyon profili çalışılmamaktadır. KPB sonrası asiyanotik çocuklarda Htk: \%27-30, siyanotik çocuklarda ise \%35-40 arasında olacak şekilde ES transfüzyonu yapılmaktadır. Sızıntı şeklinde kanama gözlendiğinde $10 \mathrm{ml} / \mathrm{kg}$ TDP, $10 \mathrm{ml} / \mathrm{kg}$ TS ve $10 \mathrm{ml} / \mathrm{kg}$ kriyopresipitat kullanılmaktadır. Postoperatif analjezi amacıyla sternumun kapatılması sırasında iv $0.15 \mathrm{mg} / \mathrm{kg}$ morfin uygulanmaktadır.

Postoperatif YBÜ yönetiminde; hasta YBÜ'ne geldiğinde rutin olarak tam kan sayımı, biyokimyasal parametreler, koagülasyon profili, arteriyel kan gazı ve laktat düzeyi çalışılmaktadır. Hipotansiyon, laktat artışı veya baz açığı ile kendini gösteren metabolik asidoz, hemodinamik instabiliteye neden olan kanama durumunda ES transfüzyonu yapılmaktadır. Koagülopati tedavisinde; $10 \mathrm{ml} / \mathrm{kg}$ TS ve $10 \mathrm{ml} / \mathrm{kg}$ kriyopresipitat kullanılmaktadır. Kanamanın devam etmesi durumunda $10 \mathrm{ml} / \mathrm{kg}$ TDP verilmektedir.

\section{İstatistiksel Analiz}

Çalışmada elde edilen kategorik ölçümler sayı ve yüzde olarak, sayısal ölçümlerse ortalama ve standart sapma (gerekli yerlerde ortanca ve minimum maksimum) olarak özetlendi. Sayısal ölçümlerin normal dağılım varsayımını sağlayıp sağlamadığı Shapiro Wilk testi ile test edildi. Gruplar (RASCH grupları, siyanotik olup olmama, mortalite gibi) arasında sayısal ölçümlerin karşılaştırılmasında varsayımların sağlanması durumunda bağımsız gruplarda T testi, varsayımların sağlanmaması durumunda ise Mann Whitney $\mathrm{U}$ testi kullanıldı. Sayısal ölçümler arasındaki 
etkileşimi incelemede varsayımların sağlanması durumunda Pearson korelasyonu, varsayımların sağlanmaması durumunda ise Spearman korelasyonu kullanıldı. Verilerin istatistiksel analizinde IBM SPSS Statistics Versiyon 20.0 paket programı kullanıldı. Tüm testlerde istatistiksel önem düzeyi 0.05 olarak alındı.

SPSS referansI: IBM Corp. Released 2011. IBM SPSS Statistics for Windows, Version 20.0. Armonk, NY: IBM Corp.

\section{BULGULAR}

Çalışmamıza KKH nedeni ile KPB uygulanarak kardiyak cerrahi geçiren 83 çocuk dâhil edildi. Çocukların demografik verileri, KKH tanıları, daha önce geçirdikleri ameliyatlar ve yandaş hastalıkları Tablo 1'de gösterildi.

Hastaların intraoperatif verileri Tablo 2'de verildi. İntraoperatif dönemde $61(\% 73,5)$ hastaya ES, 45 (\%54.2) hastaya TDP transfüzyonu yapıldığı belirlendi. Postoperatif YBÜ döneminde ise 68 (\%81.9) hastaya ES, $72(\% 86.7)$ hastaya TDP, $17(\% 20,5)$ hastaya kriyopresipitat, 33 (\%39.8) hastaya ise TS transfüzyonu yapıldığı saptandı. İntraoperatif dönemde uygulanan sıvı, kan ve kan ürünleri tüketimi Tablo 3'te gösterildi. RACHS1 skoru 3 olan hastalarda intraoperatif ve postoperatif dönemde kan ve kan ürünleri transfüzyon miktarı RACHS1 skoru 2 olan hastalardan rakamsal olarak daha büyük olmakla birlikte, yalnızca ES transfüzyon miktarı istatistiksel olarak anlamlı şekilde yüksekti $(p=0,009)$.

Yapılan korelasyon analizinde hastanın yaşı ile postoperatif dönemde uygulanan ES transfüzyonu ( $r=$ -0.224, $p=0.047$ ) ile intraoperatif ve postoperatif dönemde uygulanan toplam ES ( $r=-0.228, p=0.044)$ ve toplam TDP ( $r=-0.226, p=0.045)$ transfüzyonu arasında negatif korelasyon saptandı (Grafik 1).

Kardiyopulmoner bypass süresi ile intraoperatif ES ( $r=0.345, p=0.001)$ ve TDP $(r=0.353, p=0.001)$, postoperatif ES $(r=368, p=0.001)$, TDP $(r=329, p=0.001)$ ve kriyopresipitat $(r=0.282, p=0.011)$ tüketimi arasında zayıf pozitif korelasyon belirlendi. Ayrıca KPB süresi
Table 1. Demografik veriler.

\begin{tabular}{lcc} 
& $\begin{array}{c}\text { Ortalama } \\
\pm S D\end{array}$ & $\begin{array}{c}\text { Min- } \\
\text { maks. }\end{array}$ \\
\hline Cinsiyet (K/E) (n) & $39 / 44$ & \\
Yaš (ay) & $45.76 \pm 50.9$ & $1-192$ \\
Ağılık (kg) & $14.74 \pm 13.05$ & $3,5-60$ \\
Preoperatif Hb (mg/dL) & $13.51 \pm 3,5$ & $8.9-23.2$ \\
Preoperatif Htk (\%) & $41.41 \pm 10.6$ & $26.5-70.6$ \\
Siyanotik / Asiyanotik (n) & $31 / 52$ & \\
\hline
\end{tabular}

$\begin{array}{lc}\text { Konjenital Kalp Hastalığı (n, \%) } & \\ \text { Çift çıkışı sağ ventrikül } & 6(\% 7.2) \\ \text { Çift girişli sol ventrikül } & 2(\% 2.4) \\ \text { Triküspid atrezisi } & 17(\% 20,5) \\ \text { Büyük arter transpozisyonu } & 7(\% 8.4) \\ \text { TPVDA } & 12(\% 14,5) \\ \text { PPVDA } & 7(\% 8.4) \\ \text { AVSD } & 7(\% 8.4) \\ \text { Aort darlığı } & 5(\% 6) \\ \text { Pulmoner darlık } & 4(\% 4.8) \\ \text { Pulmoner atrezi } & 6(\% 7.2) \\ \text { VSD } & 2(\% 2.4) \\ \text { ASD+VSD } & 1(\% 1.2) \\ \text { Subaortik membran eksizyonu } & 5(\% 6) \\ \text { Truncus arteriyozus } & 1(\% 1.2) \\ \text { Fallot tetralojisi } & 1(\% 1.2)\end{array}$

$\begin{array}{cc}\text { RACHS1 Skoru (n, \%) } & \\ 2 & 34(\% 41) \\ 3 & 49(\% 59)\end{array}$

\begin{tabular}{|c|c|}
\hline \multicolumn{2}{|l|}{ Yandaş Hastalık } \\
\hline Down sendromu (n, \%) & $11(\% 13.3)$ \\
\hline Hipotiroidi (n, \%) & $3(\% 3.6)$ \\
\hline Epilepsi ( $n, \%)$ & $3(\% 3.6)$ \\
\hline Bilateral hidroüroteronefroz $(n, \%)$ & $1(\% 1.2)$ \\
\hline Mental retardasyon (n, \%) & $2(\% 2.4)$ \\
\hline \multicolumn{2}{|l|}{ Geçirilmiş Operasyon } \\
\hline Cavapulmoner anastomoz & $5(\% 6)$ \\
\hline $\begin{array}{l}\text { Fallot tetralojisi düzeltme } \\
\text { ameliyatı }\end{array}$ & $1(\% 1.2)$ \\
\hline Aortopulmoner şant & $10(\% 8.3)$ \\
\hline Pulmoner band & 1 (\%1.2) \\
\hline PDA ligasyonu & $1(\% 1.2)$ \\
\hline ASD onarımı & 1 (\%1.2) \\
\hline Aort koarktasyonu & 1 (\%1.2) \\
\hline
\end{tabular}

Veriler ortalama (ort) \pm standart sapma (SD), min-maks: minimum- maksimum, olgu sayısı (n), yüzde (\%) veya minimum-maksimum olarak belirtilmiştir.

Hb: Hemoglobin,

Htk: Hematokrit,

TPVDA: Total pulmoner venöz dönüş anomalisi, PPVDA: Parsiyel pulmoner venöz dönüş anomalisi, AVSD: Atriyoventriküler septal defekt,

VSD: Ventriküler septal defekt,

ASD: Atriyal septal defekt,

RACHS: Risk adjustment for surgery for congenital heart disease, konjenital kalp hastalığında cerrahi için risk düzenlemesi 
Table 2. Intraoperatif veriler.

\begin{tabular}{|c|c|c|}
\hline & $\begin{array}{l}\text { Ortalama } \\
\quad \pm S D\end{array}$ & $\begin{array}{l}\text { Min- } \\
\text { maks. }\end{array}$ \\
\hline KPB süresi (dk.) & $88.8 \pm 44.1$ & $20-250$ \\
\hline Kros klemp süresi (dk.) & $53.9 \pm 34.3$ & $0-170$ \\
\hline Ameliyat süresi (dk.) & $220 \pm 74.4$ & $65-480$ \\
\hline KPB öncesi Htk (\%) & $33.3 \pm 5.1$ & 34.3-53.9 \\
\hline Ameliyat sonu Htk (\%) & $35.9 \pm 4.9$ & $26.2-45.7$ \\
\hline KPB öncesi Hb (mg/dL) & $11.3 \pm 2.1$ & 8.2-17.4 \\
\hline Ameliyat sonu $\mathrm{Hb}$ (mg/dL) & $11.7 \pm 1.6$ & $8.4-14,5$ \\
\hline KPB öncesi laktat (mmol/lt) & $2.8 \pm 2$ & $0.8-14.4$ \\
\hline KPB'ta Isınma sırasında laktat (mmol/tt) & $2.4 \pm 1.7$ & $0.7-13.6$ \\
\hline KPB'tan çıkış sırasında laktat (mmol//t) & $3 \pm 2,5$ & $0.8-13.7$ \\
\hline KPB öncesi vücut ISISI $\left({ }^{\circ} \mathrm{C}\right)$ & $35.3 \pm 0.8$ & $33,5-37.4$ \\
\hline KPB'ta en düşük vücut ISISI $\left({ }^{\circ} \mathrm{C}\right)$ & $21.4 \pm 3.1$ & 20.2-35.1 \\
\hline KPB sonrası vücut ISISI ( $\left.{ }^{\circ} \mathrm{C}\right)$ & $35.6 \pm 0.8$ & $33,5-37.6$ \\
\hline KPB öncesi ScVO & $65.7 \pm 13,5$ & $27.8-89.3$ \\
\hline Ameliyat sonunda $\mathrm{ScVO}_{2}(\%)$ & $67.4 \pm 13.8$ & $31-88.7$ \\
\hline İntraoperatif idrar miktarı (ml/kg) & $26.4 \pm 25,5$ & $0.7-128.8$ \\
\hline Postoperatif $\mathrm{K}(\mathrm{mmol} / \mathrm{lt})$ & $3.4 \pm 0,5$ & 2.4-4.6 \\
\hline İnotropik skor & $10.3 \pm 10.1$ & $0-60$ \\
\hline
\end{tabular}

Veriler ortalama \pm standart sapma (SD), minimummaksimum olarak belirtilmiştir.

Min-maks.: minimum-maksimum

KPB: Kardiyopulmoner baypas,

Htk: Hematokrit,

$\mathrm{Hb}$ : Hemoglobin

$\mathrm{ScVO}_{2}$ : Santral venöz oksijen saturasyonu,

K: Potasyum
Table 3. İntraoperatif sıvı, kan ve kan ürünleri tüketimi.

\begin{tabular}{lcc} 
& $\begin{array}{c}\text { Ortalama } \\
\pm S D\end{array}$ & $\begin{array}{c}\text { Min- } \\
\text { maks. }\end{array}$ \\
\hline Intraoperatif kristalloid (mlt/kg) & $22.6 \pm 11$ & $6-60$ \\
Intraoperatif kolloid (mlt/kg) & $8.1 \pm 5.8$ & $1-15$ \\
Intraoperatif ES (mlt/kg) & $7.7 \pm 8.4$ & $0-46$ \\
Intraoperatif TDP (mlt/kg) & $5.3 \pm 6.9$ & $0-40$ \\
Intraoperatif kriyopresipitat (mlt/kg) & $3,5 \pm 2.1$ & $2-5$
\end{tabular}

Veriler ortalama \pm standart sapma (SD), minimummaksimum olarak belirtilmiştir.

Min-maks.: minimum-maksimum

ES: Eritrosit süspansiyonu

TDP: Taze donmuş plazma

ile intraoperatif ve postoperatif dönemde verilen toplam ES ( $r=0.430, p=0.000)$ ve toplam TDP ( $r=0,387$, $p=0.000)$ tüketimi arasında pozitif korelasyon belirlendi (Grafik 2). Toplam cerrahi süre ile postoperatif dönemde verilen ES ( $r=0.368, p=0.00)$, TDP ( $r=378$, $p=0.00)$ ve TS $(r=0.287, p=0.009)$ tüketimi arasında zayıf pozitif korelasyon saptandı. Ayrıca preoperatif dönemdeki $\mathrm{Hb}$ ve $\mathrm{Htk}$ değerleri ile intraoperatif dönemdeki ES tüketimi arasında zayıf pozitif korelasyon belirlendi $(r=0.292, p=0.007 ; r=0.292, p=0.07)$.

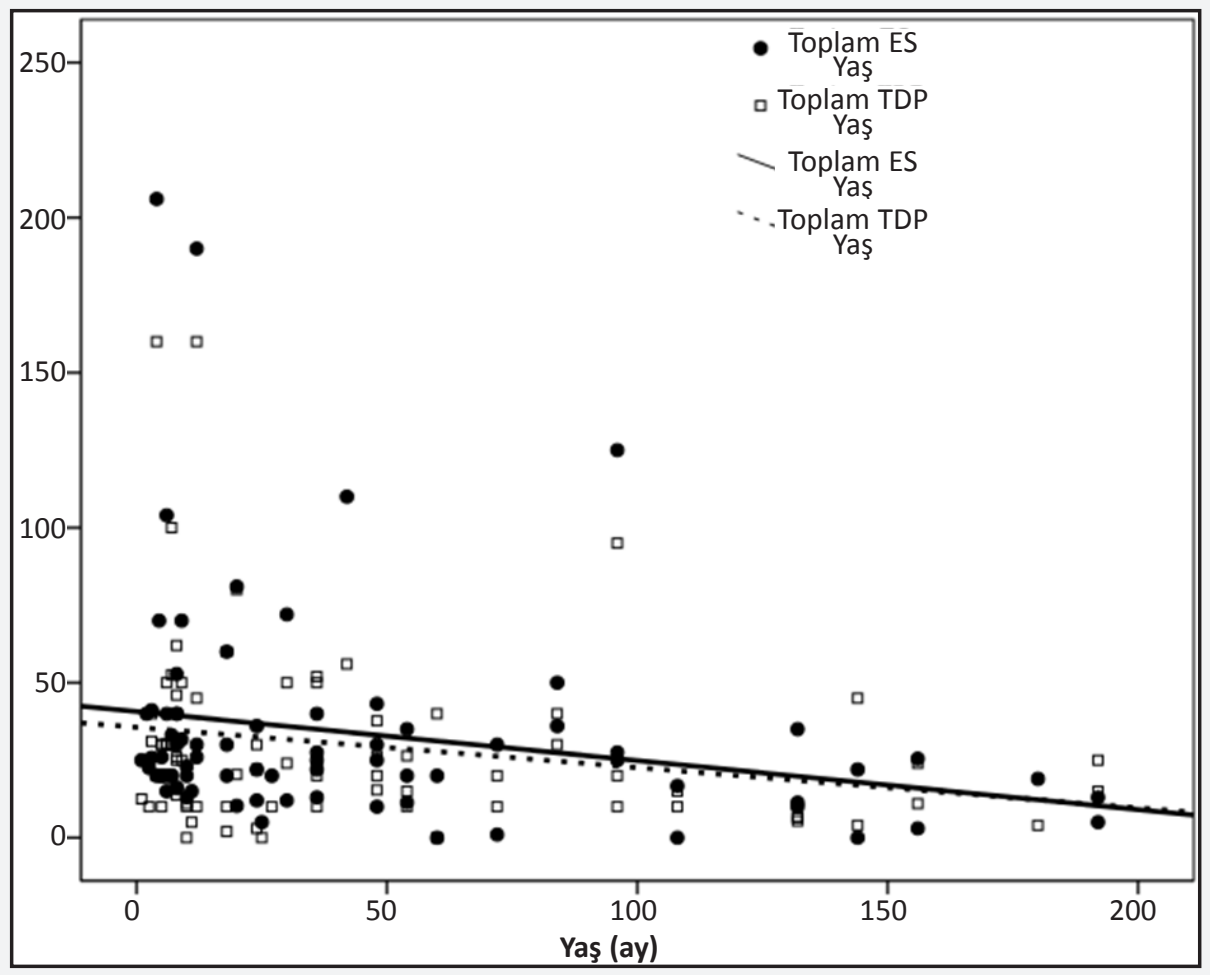

\section{Grafik 1.}




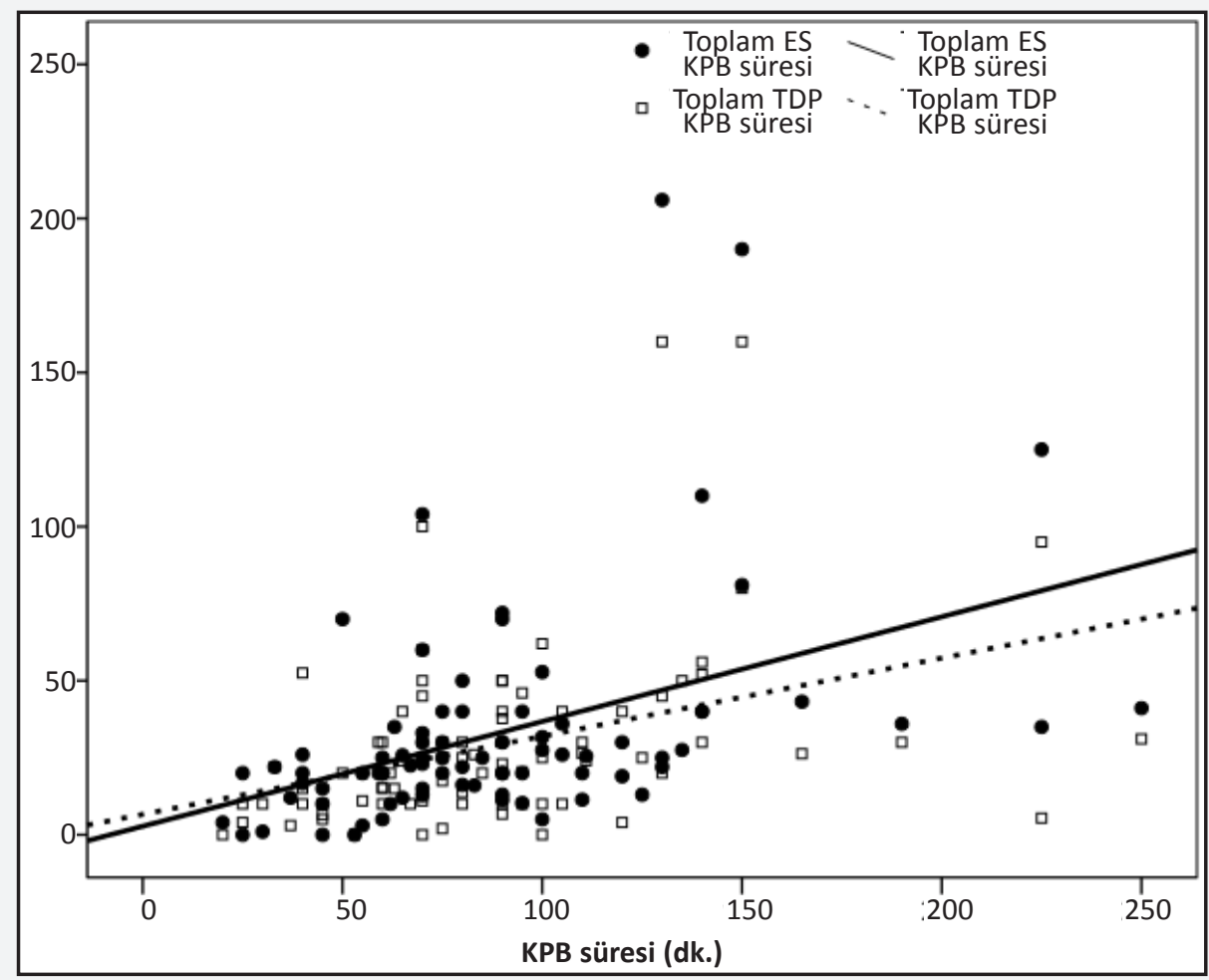

Grafik 2.

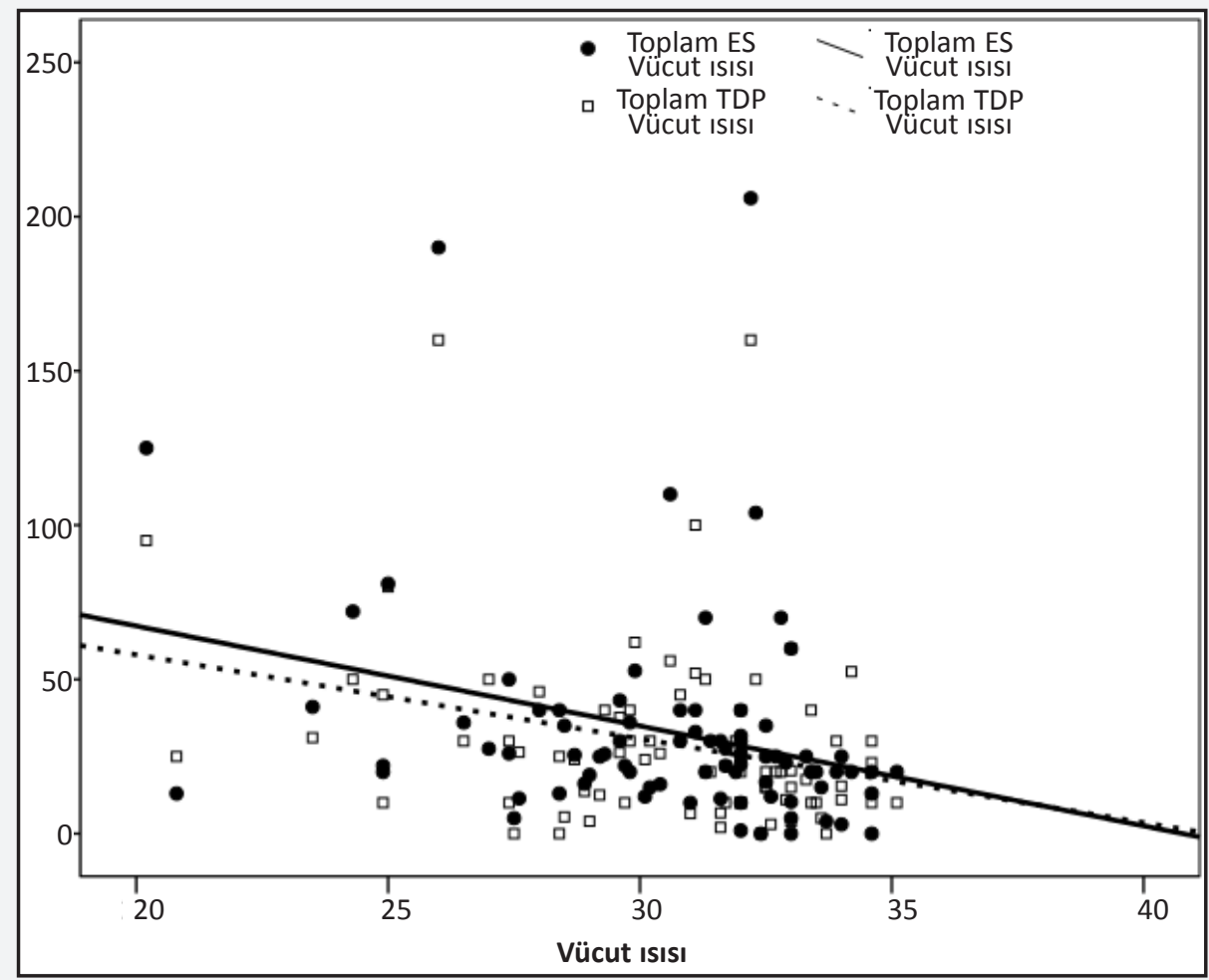

Grafik 3. 
Siyanotik ve asiyanotik çocukların intraoperatif dönemdeki kan ve kan ürünleri tüketimi karşılaştırıldığında, siyanotik çocukların intraoperatif ES ve TDP tüketimi asiyanotik çocuklardan istatistiksel olarak anlamlı şekilde yüksekti (ES $p=0.002$; TDP $p=0.002$ ). Postoperatif dönemde ise siyanotik çocukların kriyopresipitat tüketimi asiyanotik çocuklardan anlamlı şekilde yüksekti $(p=0.026)$.

Vücut ISISI ile intraoperatif dönemdeki ES ( $r=-0.407$, $p=0,00)$ ve TDP $(r=-0.323, p=0.003)$ transfüzyonu, postoperatif dönemdeki TDP $(r=-0.229, p=0.04)$ ve kriyopresipitat ( $r=-0.227, p=0.042$ ) transfüzyonu arasında negatif korelasyon belirlendi. Ayrıca vücut ISISI ile intraoperatif ve postoperatif dönemde verilen toplam ES $(r=-0,285, p=0.01)$ ve toplam TDP ( $r=$ $-0,289, p=0.009)$ tüketimi arasında negatif korelasyon belirlendi (Grafik 3).

Postoperatif dönemde YBÜ'nde uygulanan ES, TDP, kriyopresipitat ve trombosit süspansiyonu transfüzyon miktarları ile YBÜ'nde ve hastanede yatış süreleri Tablo 4'te gösterildi. YBÜ'nde yatış süresi ile IS ( $r=$ $0.248, p=0.027)$ ve intraoperatif ES tüketimi ( $r=0.275$, $\mathrm{p}=0.014$ ) arasında zayıf pozitif korelasyon saptandı.

Tüm hastaların YBÜ’ne entübe şekilde çıkarıldığı belirlendi. İki hastanın operasyon sonunda ekstrakorporeal membran oksijenizasyon sistemi (ECMO) kurularak YBÜ'ne çıkarıldığı, 3 hastaya ise YBÜ’nde ECMO uygulandığı tespit edildi. Ancak bu 5 hastanın da kardiyak yetmezlik sonucu eksitus olduğu saptandı. Dokuz hastanın postoperatif dönemde solunum ve dolaşım yetmezliği nedeniyle eksitus olduğu, 1 hastanın ise kanama nedeniyle 2 kez opere edildikten sonra kaybedildiği saptandı (Tablo 4). Eksitus olan hastalarda postoperatif dönemde uygulanan ES ve TDP miktarının yaşayan hastalara göre istatistiksel olarak anlamlı şekilde yüksek olduğu belirlendi ( $E S p=0.004, T D P p=0.003)$. Intraoperatif ve postoperatif dönemde uygulanan toplam ES ve TDP miktarı aynı şekilde eksitus olan hastalarda anlamlı şekilde yüksekti (toplam ES p=0.001, toplam TDP $\mathrm{p}=0.003$ ).
Table 4. Postoperatif veriler.

\begin{tabular}{lcc} 
& $\begin{array}{c}\text { Ortalama } \\
\pm \text { ISD }\end{array}$ & $\begin{array}{c}\text { Min- } \\
\text { maks. }\end{array}$ \\
\hline YBÜ’nde ES transfüzyonu & $25.4 \pm 33.1$ & $0-206$ \\
YBÜ'nde TDP transfüzyonu & $23.9 \pm 26.9$ & $0-152$ \\
YBÜ'nde kriyopresipitat transfüzyonu & $3.1 \pm 4.7$ & $0-20$ \\
YBÜ’nde trombosit transfüzyonu & $4.9 \pm 8.4$ & $0-50$ \\
YBÜ’nde kalıs süresi (gün) & $6.1 \pm 4.1$ & $1-18$ \\
Hastanede kalı̧s süresi (gün) & $10.3 \pm 5.9$ & $1-33$ \\
Mortalite (n, \%) & $15(\% 18.07)$ &
\end{tabular}

Veriler ortalama \pm standart sapma (SD), Min-maks (minimum-maksimum) olarak belirtilmiştir.

YBÜ: Yoğun bakım ünitesi,

ES: Eritrosit süspansiyonu,

TDP: Taze donmuş plazma

Postoperatif dönemde 5 hastanın kalıcı pil uygulanmak üzere yeniden ameliyata alındığı belirlendi.

\section{TARTIŞMA}

Çalışmamızda, açık kalp cerrahisi geçiren çocuk hastalarda intraoperatif ve postoperatif transfüzyon oranlarının hastanın yaşı, RACHS1 skoru, KPB süresi, ameliyat süresi, intraoperatif vücut ISISI, hastanın siyanotik olup olmaması, YBÜ'nde yatış süresi ve mortalite ile ilişkili olduğu belirlenmiştir.

Özellikle yenidoğan ve infantlar başta olmak üzere, pediatrik hastalarda hemodilüsyon ve yetersiz koagülasyon nedeniyle KPB sonrası hemoraji sık görülmektedir ${ }^{[13,14]}$. KKH'nın geniş spektrumu, hastanın siyanotik olup olmaması, uygulanan cerrahi yöntem gibi faktörler nedeniyle bu hastalarda transfüzyon eşiği için bir değer belirlemek kolay değildir ${ }^{[10]}$. Ayrıca bazı çalışmalarda yüksek $\mathrm{Hb}$ değerlerinin perioperatif sonuçlar ve nörolojik gelişimi optimize ettiği savunulurken ${ }^{[15-17]}$, diğer taraftan kan ürünlerinin zararlarından ve sıklıkla gereksiz transfüzyon yapıldığından söz edilmektedir ${ }^{[18,19]}$. Pediatrik kalp cerrahisi geçiren çocuklarda, hemodilüsyona bağlı koagülasyon yetersizliği nedeniyle trombosit, fibrinojen ve koagülasyon faktörlerinin transfüzyonu sıklıkla gerekmektedir. Ancak, bu hastaların farklı fizyolojik durumları nedeniyle replasman oranları tanımlanamamıştır ${ }^{[10]}$. 
Kan transfüzyonu oksijen taşıma kapasitesini ve doku oksijenizasyonunu arttırmaktadır ${ }^{[9]}$. Aynı zamanda eritrositler reolojik etkileri ile ${ }^{[20]}$ ve trombosit aktivasyonu sağlayarak hemostazise katkıda bulunmaktadır ${ }^{[21]}$. Ancak, kalp cerrahisi geçiren pediatrik hastalarda kan transfüzyonu volümü ve sıklığındaki artış, pulmoner komplikasyonlar ve infeksiyon sıklığında artış, YBÜ ve hastanede kalış süresinde uzama ile ilişkilidir ${ }^{[6-8]}$.

Kardiyak cerrahi geçiren pediatrik hastalarda kan transfüzyonu miktarını, yalnızca intraoperatif kan kaybı veya preoperatif $\mathrm{Htk}$ değerine göre belirlemek mümkün değildir ${ }^{[22]}$. Hastaya ait özellikler, cerrahi prosedür ve tedavi süreci transfüzyon miktarını etkilemektedir ${ }^{[23]}$. Richmond ve ark. ${ }^{[24]}$ RACHS ile belirlenen daha kompleks kardiyak ameliyatlar geçiren çocuklarda kan transfüzyon oranlarının daha yüksek olduğunu belirlemişlerdir. Kompleks kardiyak anomalilere sahip çocukların KPB süresi ve toplam ameliyat süresi de uzun olmaktadır. Szekely ve ark. ${ }^{[23]}$ operasyon süresinin kan transfüzyonunda bağımsız bir belirleyici olduğunu bildirmişlerdir. Çalışmamızda, da, benzer şekilde, RACHS1=3 olan çocuklarda ES transfüzyon miktarı RACHS1=2 olan çocuklardan anlamlı şekilde yüksek bulunmuştur ( $p=0.009)$. Ayrıca KPB süresi ile intraoperatif ES ve TDP, postoperatif ES, TDP ve kriyopresipitat tüketimi, intraoperatif ve postoperatif dönemde verilen toplam ES ve toplam TDP tüketimi arasında pozitif korelasyon belirlenmiştir.

Pediatrik kalp cerrahisinde hastanın yaşı ile ilgili birçok faktör kanama miktarında artışa neden olabilmektedir ${ }^{225]}$. Yenidoğan ve infantlar küçük vücut yüzey alanları ve ağırlıkları nedeniyle rölatif olarak daha büyük volümde priming solüsyon gerektirmektedir ${ }^{[26]}$. Ayrıca bu hastalarda preoperatif dönemde koagülasyon yetersizlikleri daha sık gözlenmektedir ${ }^{[27]}$. Naguib ve ark. ${ }^{[28]}$ kardiyak cerrahi geçiren yenidoğan ve çocuklarda yaptıkları çalışmalarında küçük yaşta ve düşük vücut ağırlığı olan hastalarda kan ve kan ürünleri tüketiminin daha fazla olduğunu bildirmişlerdir. Çalışmamızda da, benzer şekilde, hastanın yaşı ile postoperatif dönemde uygulanan ES transfüz- yonu ile intraoperatif ve postoperatif dönemde uygulanan toplam ES ve toplam TDP transfüzyonu arasında negatif korelasyon saptandı.

Faraoni ve ark. ${ }^{[29]} 150$ pediatrik hastayı değerlendirdikleri çalışmalarında, siyanotik KKH'nın postoperatif kanama için bağımsız bir risk faktörü olduğunu bildirmişlerdir. Altı yüz elli yedi hastanın değerlendirildiği retrospektif bir çalışmada ise, siyanotik hastalara daha fazla kan transfüzyonu yapıldığı saptanmıştır [23]. Özellikle Htk değeri >\%50 olan siyanotik hastalarda koagülasyon zamanı uzamakta, fibrinojen düzeyi azalmakta ve trombositopeni görülmektedir ${ }^{[30]}$. Çalışmamızda ise, siyanotik çocukların intraoperatif ES ve TDP tüketiminin asiyanotik çocuklardan istatistiksel olarak anlamlı şekilde yüksek olduğu, postoperatif dönemde ise siyanotik çocukların kriyopresipitat tüketiminin asiyanotik çocuklardan fazla olduğu belirlenmiştir.

Mulaj ve ark. ${ }^{[22]}$ kardiyak cerrahi geçiren 334 pediyatrik hastayı inceledikleri retrospektif çalışmalarında, anemi, hemodilüsyon ve hipoterminin ES transfüzyon miktarı ile ilişkili olduğunu bildirmişlerdir. Kardiyak cerrahi geçiren erişkin hastalarda yapılan çalışmalar$\mathrm{da}$, demir replasmanı ile preoperatif dönemde $\mathrm{Hb}$ düzeyi arttırılarak kan transfüzyonunun azaltılabileceği gösterilmiştir ${ }^{[31]}$. Pediyatrik hastalarda demir eksikliği anemisi sık görülmekte ve tanı kolaylıkla koyulabilmektedir. Ancak bu hasta grubunda preoperatif dönemde demir replasmanı ve kan transfüzyon miktarına etkisi ile ilgili yeterli çalışma bulunmamaktadır ${ }^{[22]}$. Kliniğimizde preoperatif $\mathrm{Hb}$ değeri $9 \mathrm{mg} / \mathrm{dL}$ 'nin altında olan hastalarda (acil durumlar dışında) anemi tedavisi uygulanmakta ve $\mathrm{Hb}$ değeri yükseldikten sonra ameliyat yapılmaktadır.

Pediatrik açık kalp cerrahisinde hipotermi, hücresel metabolizmayı azaltarak beyin, böbrekler gibi organları iskemik hasardan korumak amacıyla sıklıkla uygulanmaktadır ${ }^{[32]}$. Ayrıca hipotermi ile KPB'a inflamatuar yanıt da azalmaktadır ${ }^{[33]}$. Ancak derin hipotermik sirkülatuar arrest, hipotermi, KPB süresinin uzun olması veya tüm bu faktörlerin kombinasyonu, kana- 
mayı ve transfüzyon oranını arttırmaktadır [26,27] Çalışmamızda, ulaşılan en düşük vücut ısısı ile intraoperatif dönemdeki ES ve TDP transfüzyonu, postoperatif dönemdeki TDP ve kriyopresipitat transfüzyonu ve intraoperatif ve postoperatif dönemdeki toplam ES ve toplam TDP tüketimi arasında negatif korelasyon belirlenmiştir.

Konjenital kalp hastalığı nedeniyle açık kalp cerrahisi geçiren bir çocukta, hedef $\mathrm{Hb}$ düzeyi genellikle hastaya bağlı olarak, bireysel şekilde belirlenmektedir. Pediyatrik YBÜ'nde transfüzyon gereksinimlerini araştıran TRIPICU (The Transfusion Requirements in the Pediatric Intensive Care Unit) çalışmasında $\mathrm{Hb}: 7$ $\mathrm{mg} / \mathrm{dl}$ düzeyinin YBÜ’nde tedavi edilen çocuklar tarafından yan etkiler gözlenmeden tolere edildiği bildirilmişsir ${ }^{[19]}$. Yapılan subgrup analizinde postoperatif kardiyak cerrahi hastalarında restriktif transfüzyon stratejisi uygulanan çocuklarla $(\mathrm{Hb}: 7 \mathrm{mg} / \mathrm{dl}$ ) liberal transfüzyon stratejisi $(\mathrm{Hb}: 9,5 \mathrm{mg} / \mathrm{dl})$ uygulanan çocuklar arasında multisistem organ disfonksiyon düzeyleri arasında bir fark gözlenmemiştir ${ }^{[34]}$. Ancak randomize kontrollü çalışmalarda, KPB sırasında Htk: \%20 oranında takip edilen pediatrik hastalarda, Htk düzeyi \%30 olacak şekilde transfüzyon yapılan hastalara göre, daha düşük postoperatif kardiyak indeks, daha yüksek laktat düzeyleri ve kötü nörolojik gelişim sonuçları rapor edilmiştir [15]. Daha sonra yapılan çalışmalarda ise,klinik sonuçlar ve nörolojik gelişim açısından \%24 düzeyindeki Htk oranının yeterli olduğu bildirilmiştir ${ }^{[34,35]}$. Ancak yenidoğanlar, siyanotik hastalar ve çok farklı kardiyak profile sahip hastalarda daha yüksek $\mathrm{Htk}$ düzeyleri gerekebilmektedir. Dolayısıyla KPB'tan ayrılırken hedef $\mathrm{Hb}$ düzeyini standardize edebilmek mümkün olmamakta ve anestezist, cerrah ve perfüzyonisitin düşünce birliği ile ve her hasta için bireyselleştirilerek karar verilmesi gerekmektedir ${ }^{[10]}$. Kliniğimizde KPB sırasında Htk değerinin \%28-30 oranında olması sağlanmakta ve KPB'tan ayrilırken asiyanotik çocuklarda Htk: \%27-30, siyanotik çocuklarda ve yenidoğanlarda ise Htk: \%35-40 düzeyinde olacak şekilde transfüzyon planlanmaktadır.

Daha önce yapılmış çalışmalarda, kardiyak cerrahi geçiren pediatrik hastalarda, artan kan ve kan ürünleri transfüzyonu ile postoperatif dönemde mekanik ventilasyon tedavi süresinde, YBÜ'nde ve hastanede yatış süresinde uzama olduğu gösterilmiştir ${ }^{[36-38]}$. Çalışmamızda, ne yazık ki postoperatif mekanik ventilasyon tedavi süresi değerlendirilememiştir. Ancak, YBÜ'nde yatış süresi ile intraoperatif ES tüketimi arasında pozitif korelasyon saptanmıştır. Ayrıca çalışmamızda eksitus olan hastalarda ES ve TDP transfüzyon miktarı yaşayan hastalardan istatistiksel olarak anlamlı şekilde yüksek olduğu belirlenmiştir.

\section{SONUC}

Sonuç olarak, çalışmamızda KKH nedeniyle açık kalp cerrahisi geçiren çocuklarda intraoperatif ve postoperatif transfüzyon oranlarının hastanın yaşı, RACHS1 skoru, KPB süresi, ameliyat süresi, intraoperatif vücut ISISI, hastanın siyanotik olup olmaması ile ilişkili olduğu belirlenmiştir. Ayrıca çalışmamız kapsamında, postoperatif eksitus olan hastalarda ES ve TDP miktarlarının anlamlı şekilde yüksek olduğu saptanmıştır. Bu konuda prospektif ve randomize kontrollü çalışmalara gereksinim olmasına rağmen, çalışmamızdan ve daha önce yapılan çalışmalardan elde edilen veriler sonucunda, bu hasta grubunda kan ve kan ürünleri transfüzyonu uygulanırken zararlı etkiler göz önünde bulundurulmalı ve her hastada bireysel şekilde transfüzyon kararı verilmelidir.

\section{KAYNAKLAR}

1. Kern FH, Morana NJ, Sears JJ, Hickey PR. Coagulation defects in neonates during cardiopulmonary bypass. Ann Thorac Surg. 1992;54:541-6. https://doi.org/10.1016/0003-4975(92)90451-9

2. Hornykewycz S, Odegard KC, Castro RA, Zurakowski D, Pigula F, DiNardo JA. Hemostatic consequences of a nonfresh or reconstituted whole blood small volume cardiopulmonary bypass prime in neonates and infants. Paediatr Anaesth. 2009;19:854-61. https://doi.org/10.1111/j.1460-9592.2009.03110.x

3. Ferraris VA, Ferraris SP, Saha SP, Hessel EA 2nd, Haan $\mathrm{CK}$, Royston $\mathrm{BD}$ et al. Perioperative blood transfusion and blood conservation in cardiac surgery: the Society of Thoracic Surgeons and the Society of Cardiovascular Anesthesiologists clinical practice guideline. Ann 
Thorac Surg. 2007;83(5 Suppl.):S27-86.

https://doi.org/10.1016/j.athoracsur.2007.02.099

4. Durandy Y. Use of blood products in pediatric cardiac surgery. Artif Organs. 2015;39:21-7.

https://doi.org/10.1111/aor.12447

5. Keung CY, Smith KR, Savoia HF, Davidson AJ. An audit of transfusion of red blood cell units in pediatric anesthesia. Paediatr Anaesth. 2009;19:320-8. https://doi.org/10.1111/j.1460-9592.2009.02939.x

6. Costello JM, Graham DA, Morrow DF, Morrow J, Potter-Bynoe G, Sandora TJ, et al. Risk factors for surgical site infection after cardiac surgery in children. Ann Thorac Surg. 2010;89:1833-41; discussion 1841-2. https://doi.org/10.1016/j.athoracsur.2009.08.081

7. Kipps AK, Wypij D, Thiagarajan RR, Bacha EA, Newburger JW. Blood transfusion is associated with prolonged duration of mechanical ventilation in infants undergoing reparative cardiac surgery. Pediatr Crit Care Med. 2011;12:52-6.

https://doi.org/10.1097/PCC.0b013e3181e30d43

8. Salvin JW, Scheurer MA, Laussen PC, Wypij D, Polito A, Bacha EA et al. Blood transfusion after pediatric cardiac surgery is associated with prolonged hospital stay. Ann Thorac Surg. 2011;91:204-10. https://doi.org/10.1016/j.athoracsur.2010.07.037

9. Guzzetta NA. Benefits and risks of red blood cell transfusion in pediatric patients undergoing cardiac surgery. Paediatr Anaesth. 2011;21:504-11. https://doi.org/10.1111/j.1460-9592.2010.03464.x

10. Machovec KA, Jooste EH. Pediatric transfusion algorithms: Coming to a cardiac operating room near you. J Cardiothorac Vasc Anesth. 2019 Jul;33(7):2017-29. https://doi.org/10.1053/j.jvca.2018.12.008

11. Jenkins KJ, Gauvreau K, Newburger JW, Spray TL, Moller JH, lezzoni LI. Consensus-based method for risk adjustment for surgery for congenital heart disease. J Thorac Cardiovasc Surg. 2002;123:110-8. https://doi.org/10.1067/mtc.2002.119064

12. Gaies MG, Gurney JG, Yen AH, Napoli ML, Gajarski RJ, Ohye RG, et al. Vasoactive-inotropic score as a predictor of morbidity and mortality in infants after cardiopulmonary bypass. Pediatr Crit Care Med. 2010;11:234-8.

https://doi.org/10.1097/PCC.0b013e3181b806fc

13. Hornykewycz S, Odegard KC, Castro RA, Zurakowski D, Pigula F, DiNardo JA. Hemostatic consequences of a non-fresh or reconstituted whole blood small volume cardiopulmonary bypass prime in neonates and infants. Paediatr Anaesth. 2009;19:854-61. https://doi.org/10.1111/j.1460-9592.2009.03110.x

14. Eaton MP. Antifibrinolytic therapy in surgery for congenital heart disease. Anesth Analg. 2008;106:1087-100. https://doi.org/10.1213/ane.0b013e3181679555
15. Jonas RA, Wypij D, Roth SJ, Bellinger DC, Visconti KJ, du Plessis AJ, et al. The influence of hemodilution on outcome after hypothermic cardiopulmonary bypass: results of a randomized trial in infants. J Thorac Cardiovasc Surg. 2003;126:1765-74.

https://doi.org/10.1016/j.jtcvs.2003.04.003

16. Newburger JW, Jonas RA, Soul J, Kussman BD, Bellinger DC, Laussen PC, et al. Randomized trial of hematocrit $25 \%$ versus $35 \%$ during hypothermic cardiopulmonary bypass in infant heart surgery. J Thorac Cardiovasc Surg. 2008;135:347-54, 54 e1-4. https://doi.org/10.1016/j.jtcvs.2007.01.051

17. Wypij D, Jonas RA, Bellinger DC, Del Nido PJ, Mayer JE $J r$, Bacha EA, et al. The effect of hematocrit during hypothermic cardiopulmonary bypass in infant heart surgery: results from the combined Boston hematocrit trials. J Thorac Cardiovasc Surg 2008;135:355-60. https://doi.org/10.1016/j.jtcvs.2007.03.067

18. Willems A, Harrington K, Lacroix J, Biarent D, Joffe AR, Wensley $D$ et al. Comparison of two red-cell transfusion strategies after pediatric cardiac surgery: a subgroup analysis. Crit Care Med. 2010;38:649-56. https://doi.org/10.1097/CCM.0b013e3181bc816c

19. Lacroix J, Hebert PC, Hutchison JS, Hume HA, Tucci M, Ducruet $T$ et al. Transfusion strategies for patients in pediatric intensive care units. N Engl J Med. 2007;356:1609-19. https://doi.org/10.1056/NEJMoa066240

20. Uijttewaal WS, Nijhof EJ, Bronkhorst PJ, Den Hartog E, Heethaar RM. Near-wall excess of platelets induced by lateral migration of erythrocytes in flowing blood. Am J Physiol. 1993;264:H1239-44. https://doi.org/10.1152/ajpheart.1993.264.4.H1239

21. Santos MT, Valles J, Aznar J, Marcus AJ, Broekman MJ, Safier LB. Prothrombotic effects of erythrocytes on platelet reactivity. Reduction by aspirin. Circulation 1997;95:63-8.

https://doi.org/10.1161/01.CIR.95.1.63

22. Mulaj M, Faraoni D, Willems A, Sanchez Torres C, Van der Linden P. Predictive factors for red blood cell transfusion in children undergoing noncomplex cardiac surgery. Ann Thorac Surg. 2014;98:662-7. https://doi.org/10.1016/j.athoracsur.2014.04.089

23. Szekely A, Cserep Z, Sapi E, Breuer T, Nagy CA, Vargha $P$, et al. Risks and predictors of blood transfusion in pediatric patients undergoing open heart operations. Ann Thorac Surg. 2009;87:187-97. https://doi.org/10.1016/j.athoracsur.2008.09.079

24. Richmond ME, Charette K, Chen JM, Quaegebeur JM, Bacha $E$. The effect of cardiopulmonary bypass prime volume on the need for blood transfusion after pediatric cardiac surgery. J Thorac Cardiovasc Surg. 2013;145:1058-64. 
https://doi.org/10.1016/j.jtcvs.2012.07.016

25. Williams GD, Bratton SL, Riley EC, Ramamoorthy C. Association between age and blood loss in children undergoing open heart operations. Ann Thorac Surg. 1998;66:870-5. https://doi.org/10.1016/S0003-4975(98)00600-6

26. Petaja J, Lundstrom U, Leijala M, Peltola K, Siimes MA. Bleeding and the use of blood products after heart operations in infants. J Thorac Cardiovasc Surg. 1995;109:524-9. https://doi.org/10.1016/S0022-5223(95)70284-9

27. Williams GD, Bratton SL, Ramamoorthy C. Factors associated with blood loss and blood product transfusions: a multivariate analysis in children after open-heart surgery. Anesth Analg. 1999;89:57-64. https://doi.org/10.1213/00000539-199907000-00011

28. Naguib AN, Winch PD, Tobias JD, Simsic J, Hersey D, Nicol K, et al. A single-center strategy to minimize blood transfusion in neonates and children undergoing cardiac surgery. Paediatr Anaesth. 2015;25:477-86 https://doi.org/10.1111/pan.12604

29. Faraoni D, Willems A, Romlin BS, Belisle S, Van der Linden P. Development of a specific algorithm to guide haemostatic therapy in children undergoing cardiac surgery: a single-centre retrospective study. Eur J Anaesthesiol. 2015;32:320-9. https://doi.org/10.1097/EJA.0000000000000179

30. Sambasivan A, Tibble A, Donahue BS. Low arterial saturation is associated with increased sensitivity to activated protein $\mathrm{C}$ in children with congenital heart disease. J Cardiothorac Vasc Anesth. 2006;20:38-44. https://doi.org/10.1053/j.jvca.2005.03.025

31. Cladellas M, Farre N, Comín-Colet J, Gómez M, Meroño $\mathrm{O}$, Bosch MA, et al. Effects of preoperative intravenous erythropoietin plus iron on outcome in anemic patients after cardiac valve replacement. Am J Cardiol. 2012;110:1021-6. https://doi.org/10.1016/j.amjcard.2012.05.036

32. Birdi I, Caputo M, Underwood M, Angelini GD, Bryan AJ. Influence of normothermic systemic perfusion temperature on cold myocardial protection during coronary artery bypass surgery. Cardiovasc Surg. 1999;7:369-74. https://doi.org/10.1016/S0967-2109(98)00150-1

33. Birdi I, Caputo M, Underwood M, Bryan AJ, Angelini GD. The effects of cardiopulmonary bypass temperature on inflammatory response following cardiopulmonary bypass. Eur J Cardiothorac Surg.1999;16:540-5. https://doi.org/10.1016/S1010-7940(99)00301-2

34. Willems A, Harrington K, Lacroix J, Biarent D, Joffe AR, Wensley $D$, et al. Comparison of two red-cell transfusion strategies after pediatric cardiac surgery: a subgroup analysis. Crit Care Med. 2010;38:649-56. https://doi.org/10.1097/CCM.0b013e3181bc816c

35. Budak AB, McCusker K, Gunaydin S. A structured blood conservation program in pediatric cardiac surgery. Eur Rev Med Pharmacol Sci. 2017;21:1074-9.

36. Kipps AK, Wypij D, Thiagarajan RR, Bacha EA, Newburger JW. Blood transfusion is associated with prolonged duration of mechanical ventilation in infants undergoing reparative cardiac surgery. Pediatr Crit Care Med. 2011;12:52-6. https://doi.org/10.1097/PCC.0b013e3181e30d43

37. Kneyber MC, Hersi MI, Twisk JW, Markhorst DG, Plötz FB. Red blood cell transfusion in critically ill children is independently associated with increased mortality. Intensive Care Med. 2007;33:1414-22. https://doi.org/10.1007/s00134-007-0741-9

38. Redlin M, Kukucka M, Boettcher W, Schoenfeld $H$, Huebler M, Kuppe $\mathrm{H}$, Habazettl H. Blood transfusion determines postoperative morbidity in pediatric cardiac surgery applying a comprehensive blood-sparing approach. J Thorac Cardiovasc Surg. 2013;146:537-42. https://doi.org/10.1016/j.jtcvs.2012.09.101 